\title{
PERSEPSI PETANI TERHADAP VARIETAS UNGGUL BARU INPARI 30 DAN 33 DI DESA TANJUNGSARI KECAMATAN BANYUDONO KABUPATEN BOYOLALI
}

\section{FARMERS' PERCEPTION ON NEW SUPERIOR CULTIVARS OF INPARI 30 AND 33 IN TANGJUNGSARI VILLAGE OF BANYUDONO SUBDISTRICT OF BOYOLALI REGENCY}

\author{
Denissa Ayu Ningtyas, Suwarto, Arip Wijianto \\ Program Studi Penyuluhan dan Komunikasi Pertanian Fakultas \\ Pertanian \\ Universitas Sebelas Maret Surakarta \\ Jl. Ir. Sutami No. 36 A Kentingan Surakarta 57126 Telp./Fax (0271) \\ 637457 \\ Email: denissa202@gmail.com/Telp.082379905704
}

\begin{abstract}
This research aimed to analyze the farmers' perception, to analyze the factors composing the farmers' perception, to analyze the relationship between factors composing perception and the farmers' perception on new superior cultivars of Inpari 30 and 33, and to analyze the difference of perception between the farmers using Inpari 30 and 33 new superior cultivars and those not using them. The fundamental research method employed was a descriptive qualitative with survey technique. The research location was determined purposively. The sample was taken using Quota Random Sampling, consisting of 60 respondents. Data analysis was carried out using Spearman's rank and Mann Whitney's $U$ analyses. The result of research showed that there was a very significant relationship between non-formal education and farmers' perception on Inpari 30 and 33 new superior cultivars, at significance level of $99 \%$. Meanwhile, age, formal education, length of time becoming farmers, land width, and land ownership factors were not correlated significantly. There was a difference of perception between the farmers and those using Inpari 30 and 33 new superior cultivars.
\end{abstract}

Keywords : Farmer's Perception, Inpari 30 and 33 new superior, Rank Spearman, U Mann Whitney

Abstrak: Penelitian ini bertujuan untuk menganalisis persepsi petani, menganalisis faktor-faktor pembentuk persepsi petani, menganalisis hubungan antara faktor-faktor pembentuk persepsi petani terhadap varietas unggul baru Inpari 30 dan 33 dan menganalisis perbedaan antara persepsi petani pengguna VUB Inpari 30 dan 33 dengan petani yang tidak menggunakan VUB Inpari 30 dan 33. Metode dasar penelitian adalah metode desktiptif kuantitatif dengan teknik survei. Lokasi penelitian ditentukan secara purposive. Pengambilan sampel dilakukan dengan quota random sampling dengan jumlah 60 responden. Analisis data menggunakan rumus lebar interval, metode analisis korelasi rank Spearman $\left(r_{s}\right)$ dan $U$ Mann-Whitney. Hasil penelitian menunjukkan bahwa terdapat hubungan yang sangat signifikan antara 


\section{Jurnal Agritexts Volume 42 Nomer 1 Mei 2018}

pendidikan non formal dengan persepsi petani terhadap varietas unggul baru Inpari 30 dan 33, pada taraf kepercayaan sebesar 99\%. Sedangkan untuk faktor umur, pendidikan formal, lama berusahatani, luas lahan dan status kepemilikan lahan tidak memiliki hubungan yang signifikan. Terdapat perbedaan yang signifikan antara persepsi petani pengguna VUB Inpari 30 dan 33 dengan persepsi petani yang tidak menggunakan VUB Inpari 30 dan 33.

Kata Kunci : Persepsi Petani, Rank Spearman, U Mann-Whitney, Varietas Unggul Barulnpari 30 dan 33

\section{PENDAHULUAN}

Beras merupakan bahan pangan pokok bagi penduduk Indonesia. Usahatani padi menyediakan lapangan pekerjaan dan sebagai sumber pendapatan bagi rumah tangga pertanian. Sektor pertanian utamanya komoditas padi masih menjadi komoditas yang sangat strategis, sebagai bahan penghasil beras dan dimanfaatkan sebagai pangan sebagian besar masyarakat Indonesia. Produksi padi terkait dengan banyak faktor salah satunya adalah penggunaan varietas unggul baru yang dikeluarkan oleh Badan Litbang Pertanian. Pemilihan varietas unggul yang sesuai dengan lingkungan dan lahan yang akan ditanami sangat berperan penting dalam produktivitas dan kualitas beras yang dihasilkan nantinya.

Salah satu upaya untuk meningkatkan produktivitas padi adalah mengembangkan varietas unggul baru yang berdaya hasil tinggi dan adaptif pada lingkungan tertentu. Untuk itu diperlukan benih bermutu prima. Kemudahan memperoleh benih yang bermutu diperlukan petani untuk meningkatkan produksi komoditasnya (Saenong et al., 2007).

Menurut Londra dan Aribawa (2014), varietas unggul merupakan komponen teknologi yang andal dan cukup besar sumbangannya dalam meningkatkan produksi dan produktivitas padi nasional. Hingga saat ini Kementerian Pertanian, melalui Badan Litbang Pertanian telah melepas lebih dari 233 varietas unggul yang terdiri atas 144 varietas unggul padi sawah inhibrida (Inpari).

Varietas unggul merupakan salah satu komponen paket teknologi budidaya padi yang secara nyata dapat meningkatkan produktivitas dan pendapatan petani. Pada tahun 2008 Balai Besar Penelitian Tanaman Padi telah melepas varietas Inbrida Padi Irigasi atau lebih dikenal dengan Inpari. Inpari adalah varietas-varietas unggul baru padi sawah yang cocok ditanam di lahan sawah irigasi (Humaida, 2009). Varietas unggul baru berdaya hasil tinggi melebihi varietas yang telah ada dibutuhkan untuk mengatasi hambatan yang kadang terjadi dalam produksi 


\section{Ningtyas, Suwarto, Wijianto, Persepsi Petani, Rank,נ,}

pangan nasional yaitu produksi per satuan luas varietas sudah terbatas dan susah ditingkatkan(Suwarto dan Prihatiningsih 2007).

Penelitian ini dilakukan di Desa Tanjungsari Kecamatan Banyudono Kabupaten Boyolali, karena Desa Tanjungsari menjadi salah satu lokasi percontohan penerapan jajar legowo super dengan menggunakanvarietas unggul baru Inpari 30 dan 33 dengan potensi hasil tinggi yakni dapat mencapai 11,1 - 11,3 ton/Ha GKP di areal seluas $40 \mathrm{Ha}$. Pengenalan varietas unggul baru Inpari 30 dan 33 kepada petani di Desa Tanjungsari dilakukan pada bulan Mei 2016 (Litbang Jateng, 2016). Pengukuran persepsi petani terhadap varietas unggul baru Inpari 30 dan 33 menarik untuk diteliti karena hasil inovasi ini baru diterapkan di wilayah Boyolali khususnya di Desa Tanjungsari Kecamatan Banyudono pada bulan Agustus 2016. Rentan waktu antara pengenalan varietas hingga penerapannya yaitu selama dua bulan.

Lokasi percontohan penerapan jajar legowo super dengan menggunakanvarietas unggul baru Inpari 30 dan 33, Desa Tanjungsari memiliki lahan persawahan seluas 123,826 Ha. Lahan sawah yang digunakan untuk penerapan varietas unggul baru Inpari 30 dan 33 seluas $40 \mathrm{Ha}$, karena ada petani pengguna VUB Inpari 30 dan 33 dan ada petani yang tidak menggunakan VUB Inpari 30 dan 33.

Tabel 1. Luas Daerah Wilayah Tanah Sawah Desa Tanjungsari

\begin{tabular}{|c|c|c|}
\hline No. & Tanah Sawah & Luas ( $\mathrm{Ha})$ \\
\hline 1. & Irigasi $1 / 2$ teknis & 117,3800 \\
\hline 2. & Irigasi Sederhana & 6,4460 \\
\hline & Jumlah & 123,8260 \\
\hline
\end{tabular}

Sumber : Monografi Desa Tanjungsari 2017

Petani merupakan pelaku informasi-informasi mengenai varieutama dalam upaya peningkatan tas ini. Keputusan petani untuk produksi padi dan persepsi petani mempunyai peranan yang penting. menerapkan varietas unggul baru Inpari 30 dan 33, dapat ditentukan Penerapan varietas baru tidak oleh faktor-faktor pembentuk terlepas dari persepsi petani terhadap varietas tersebut. Penilaian atau persepsi petani terhadap varietas unggul baru Inpari 30 dan 33 dapat dilakukan karena adanya persepsi, antara lain umur petani, tingkat pendidikan formal, pendidikan non formal, lama berusaha tani, luas lahan, status kepemilikan lahan 


\section{Jurnal Agritexts Volume 42 Nomer 1 Mei 2018}

dan petani penerima program dan tidak menerima program.

Persepsi merupakan proses aktif penggunaan pikiran sehingga menimbulkan tanggapan terhadap suatu rangsangan (Mulyana, 2001). Persepsi petani terhadap pengembangan varietas unggul baru Inpari 30 dan 33 perlu mendapat perhatian yang mendalam. Hal ini karena persepsi petani terhadap pengembangan komoditas Inpari 30 dan 33 akan mempengaruhi pemikiran petani dalam menerapkan inovasi dari Balai Besar Penelitian Padi, sehingga ada keberlanjutan penggunaan varietas unggul baru ini. Hal ini selaras dengan pendapat yang dikemukakan oleh Rogers (1983) bahwa persepsi merupakan bagian penting dalam penentuan sikap seseorang didalam tahap persuasi, tahap persuasi ini merupakan tahap dimana persepsi umum masyarakat terhadap suatu inovasi ini dibangun. Penelitian ini akan mengkaji persepsi petani terhadap varietas unggul baru Inpari 30 dan 33 di Desa Tanjungsari Kecamatan Banyudono Kabupaten Boyolali, apa saja faktor-faktor pembentuk persepsi petani terhadap varietas unggul baru Inpari 30 dan 33 di Desa Tanjungsari Kecamatan Banyudono Kabupaten Boyolali, hubungan antara faktor-faktor pembentuk persepsi dengan persepsi petani terhadap varietas unggul baru Inpari 30 dan 33 di Desa Tanjungsari
Kecamatan Banyudono Kabupaten Boyolali dan mengkaji apakah ada perbedaan persepsi petani pengguna VUB Inpari 30 dan 33 dengan petani yang tidak menggunakan VUB Inpari 30 dan 33 di Desa Tanjungsari Kecamatan Banyudono Kabupaten Boyolali.

\section{METODE PENELITIAN}

Metode dasar penelitian ini adalah dengan menggunakan met 4 de deskriptif kuantitatif. Tekııк pelaksanaan penelitian dengan teknik survei, yaitu mengambil sampel dari populasi dengan kuesioner sebagai alat pengumpul data (Singarimbun dan Effendi, 2006).Penetapan lokasi dilakukan secara purposive (sengaja) berdasarkan pertimbangan bahwa Desa Tanjungsari Kecamatan Banyudono Kabupaten Boyolali sebagai salah satu lokasi percontohan gelar teknologi sistem tanam jajar legowo super dengan menggunakan varietas unggul baru Inpari 30 dan 33.

Populasi dalam penelitian ini adalah petani yang berada di Desa Tanjungsari yaitu sebanyak 335 orang. Jumlah sampel responden penelitian sebanyak 60 orang yang ditetapkan dengan teknik quota random sampling, dengan pengambilan sampel kuota sebanyak 30 orang dari petani pengguna VUB Inpari 30 dan 33 dan sebanyak 30 orang dari petani tidak menggunakan 


\section{Ningtyas, Suwarto, Wijianto, Persepsi Petani, Rank,,,}

VUB Inpari 30 dan 33. Pemilihan individu sebagai sampel dari setiap kuota dilakukan secara acak (random).

Sumber data yang digunakan dalam penelitian ini adalah data primer dan sekunder. Teknik pengumpulan data dalam penelitian ini adalah dengan menggunakan teknik observasi, wawancara dan pencatatan. Data responden yang diperoleh akan dianalisis menggunakan metode statistik non parametrik. Untuk mengetahui faktor pembentuk persepsi petani menggunakan metode analisis deskriptif, sedangkan persepsi petani diukur menggunakan kelas kategori (lebar interval), selanjutnya pengujian penelitian ini menggunakan korelasi rank Spearman $\left(r_{s}\right)$ untuk mengetahui hubungan faktor pembentuk persepsi dengan persepsi petani, sedangkan uji beda menggunakan $U$ Mann Whitney untuk membandingkan persepsi petani pengguna VUB Inpari 30 dan 33 dengan petani yang tidak menggunakan VUB Inpari 30 dan 33. Berikut rumus hitung dari rank Spearman $\left(r_{s}\right)$ dan uji $U$ Mann Whitney.

$$
1-\frac{6 \sum_{i=1} d i^{2}}{N^{3}-N}
$$

$r_{s}=$

Keterangan :

$$
\begin{array}{ll}
r_{s}= & \begin{array}{l}
\text { koefisien korelasi rank } \\
\text { Spearman }
\end{array} \\
\mathrm{N}= & \text { jumlah sampel petani } \\
\mathrm{di}= & \begin{array}{l}
\text { selisih ranking antara } \\
\text { variabel }
\end{array}
\end{array}
$$

$U 1=n 1 n 2+\frac{n 1(n 1+1)}{2}-R 1$

$U 2=n 1 n 2+\frac{n 2(n 2+1)}{2}-R 2$

HASIL PENELITIAN DAN PEMBAHASAN

Desa Tanjungsari merupakan salah satu desa di Kecamatan Banyudono Kabupaten Boyolali yang terletak di bagian timur arah Boyolali. Desa Tanjungsari terdiri dari2 RW dan 15 RT. Desa Tanjungsari memiliki luas wilayah 203,7000 Ha. Luas tanah Desa Tanjungsari terdiri dari tanah sawah seluas $123,8260 \mathrm{Ha}$ dan tanah kering seluas $77,2500 \mathrm{Ha}$. Jumlah Penduduk tahun 2016 yaitu 2.491 jiwa, terdiri dari 1.128 laki-laki dan 1.263 perempuan. Tanaman pangan yang diusahakan di Desa Tanjungsari yaitu tanaman padi dengan rata-rata produksi $9 \mathrm{kw} / \mathrm{Ha}$ seluas $24 \mathrm{Ha}$ (Monografi Desa Tanjungsari, 2017). 


\section{Jurnal Agritexts Volume 42 Nomer 1 Mei 2018}

Tabel 1. Distribusi Responden Berdasarkan Persepsi Petani Terhadap Varietas Unggul Baru Inpari 30 dan 33

\begin{tabular}{|c|c|c|c|c|c|c|c|}
\hline \multirow[b]{2}{*}{$\begin{array}{c}\text { No } \\
\text {. }\end{array}$} & \multirow[b]{2}{*}{ Uraian } & \multirow[b]{2}{*}{ Kategori } & \multirow[b]{2}{*}{ Skor } & \multicolumn{4}{|c|}{ Distribusi } \\
\hline & & & & $\begin{array}{c}\text { Petani } \\
\text { pengguna VUB } \\
\text { Inpari } 30 \text { dan } \\
33\end{array}$ & $\begin{array}{c}\text { Petani Tidak } \\
\text { Menggunakan VUB } \\
\text { Inpari } 30 \text { dan } 33\end{array}$ & Orang & $\%$ \\
\hline \multirow[t]{5}{*}{1.} & Sistem & Sangat Buruk & $7,0-12,5$ & - & - & - & - \\
\hline & Pemelihar & Buruk & $12,6-18,1$ & - & - & - & - \\
\hline & Aan & Sedang & $\begin{array}{c}18,2- \\
23,7\end{array}$ & 8 & 19 & 27 & 45,00 \\
\hline & & Baik & $23,8-29,3$ & 21 & 11 & 32 & 53,33 \\
\hline & & Sangat Baik & $29,4-35,0$ & 1 & - & 1 & 1,67 \\
\hline \multirow[t]{5}{*}{2.} & Ketahanan & Sangat Buruk & $6,0-10,7$ & - & - & - & - \\
\hline & Terhadap & Buruk & $10,815,5$ & 4 & 26 & 30 & 50,00 \\
\hline & HPT & Sedang & $15,6-20,3$ & 21 & 4 & 25 & 41,67 \\
\hline & & Baik & $20,4-25,1$ & 5 & - & 5 & 8,33 \\
\hline & & Sangat Baik & $25,2-30,0$ & - & - & - & - \\
\hline \multirow[t]{5}{*}{3.} & Produksi & Sangat Buruk & $7,0-12,5$ & - & - & - & - \\
\hline & Padi & Buruk & $12,6-18,1$ & 1 & - & 1 & 1,67 \\
\hline & & Sedang & $18,2-23,7$ & 2 & 28 & 30 & 50,00 \\
\hline & & Baik & $23,8-29,3$ & 27 & 2 & 29 & 48,33 \\
\hline & & Sangat Baik & $29,4-35,0$ & - & - & - & - \\
\hline \multirow[t]{5}{*}{4.} & Harga & Sangat Buruk & $7,0-12,5$ & - & - & - & - \\
\hline & Beras & Buruk & $12,6-18,1$ & - & 1 & 1 & 1,67 \\
\hline & & Sedang & $18,2-23,7$ & 15 & 26 & 41 & 68,33 \\
\hline & & Baik & $23,8-29,3$ & 15 & 3 & 18 & 30,00 \\
\hline & & Sangat Baik & $29,4-35,0$ & - & - & - & - \\
\hline \multirow[t]{11}{*}{5.} & Rasa Nasi & Sangat Buruk & $7,0-12,5$ & - & - & - & - \\
\hline & & Buruk & $12,6-18,1$ & 8 & 27 & 35 & 58,33 \\
\hline & & Sedang & $18,2-23,7$ & 16 & 3 & 19 & 31,67 \\
\hline & & Baik & $23,8-29,3$ & 6 & - & 6 & 10,00 \\
\hline & & Sangat Baik & $29,4-35,0$ & - & - & - & - \\
\hline & $\begin{array}{l}\text { Persepsi } \\
\text { Total }\end{array}$ & Sangat Buruk & $34,0-61,1$ & - & - & - & - \\
\hline & & Buruk & $61,2-88,3$ & - & - & - & - \\
\hline & & Sedang & $\begin{array}{l}88,4- \\
115,5\end{array}$ & 18 & 30 & 48 & 80,00 \\
\hline & & Baik & $\begin{array}{c}115,6- \\
142,7\end{array}$ & 12 & - & 12 & 20,00 \\
\hline & & Sangat Baik & $\begin{array}{c}142,8- \\
170,0\end{array}$ & - & - & - & - \\
\hline & & Jumlah & & & & 60 & 100,00 \\
\hline
\end{tabular}

Sumber : Analisis Data Primer 2017

Persepsi Petani terhadap Varietas Unggul Baru Inpari $\mathbf{3 0}$ dan $\mathbf{3 3}$

Persepsi adalah pengalaman tentang objek, peristiwa dan hubungan yang diperoledengan menyimpulkan informasi dan menafsirkan pesan (Rakhmat, 2007). Persepsi seseorang akan mengakibat- 


\section{Ningtyas, Suwarto, Wijianto, Persepsi Petani, Rank,,,}

kan suatu proses yang membuatnya menjadi tahu, berfikir dan menilai sifat kualitas dan keadaan internal yang lain (Liliweri, 1994). Persepsi petani terhadap varietas unggul baru Inpari 30 dan 33 di Desa Tanjungsari diukur dengan metode survei dan menggunakan skala likert yang meliputi sistem pemeliharaan, ketahanan terhadap HPT, produksi padi, harga beras dan rasa nasi. Persepsi ini dikategorikan menjadi sangat buruk, buruk, sedang, baik dan sangat baik.

\section{Persepsi Petani terhadap Sistem Pemeliharaan}

Berdasarkan Tabel 1 dapat diketahui bahwa persepsi petani terhadap sistem pemeliharaan tergolong dalam kategori baik sebanyak 32 orang atau $53,33 \%$, responden dalam kategori sedang terhadap sistem pemeiliharaan sebanyak 27 orang atau $45 \%$, sedangkan yang tergolong sangat baik hanya 1 orang atau $1,67 \%$. Berdasarkan data tersebut maka dapat disimpulkan bahwa tingkat persepsi petani terhadap sistem pemeliharaan dikategorikan baik. Responden penelitian berpersepsi bahwa sistem pemeliharaan yang dilakukan untuk varietas unggul baru Inpari 30 dan 33 sama saja dengan sistem pemeliharaan varietas lokal lainnya. Pemeliharaan secara intensif dilakukan oleh petani terutama saat program jarwo super menggunakan VUB Inpari 30 dan 33 masih berjalan dan didampingi oleh BPTP Jawa Tengah meliputi penanggulangan ketika tanaman terserang hama maupun penyakit.

\section{Persepsi Petani terhadap Ketahanan Terhadap HPT}

Berdasarkan Tabel 1 dapat diketahui bahwa persepsi petani terhadap ketahanan varietas unggul baru Inpari 30 dan 33 terhadap HPT tergolong dalam kategori buruk sebanyak 30 orang atau $50 \%$. Hal ini menunjukkan bahwa ketahanan padi terhadap HPT tergantung dari masa tanam yang dilakukan. Varietas unggul baru Inpari 30 dan 33 sangat cocok bila ditanam pada masa tanam tiga, karena cuaca yang cenderung bukan musim penghujan sehingga mendukung dan jarang terserang hama wereng batang coklat, penyakit blast (potong leher) dan hawar daun bakteri (penyakit kresek). Menurut Ndambiri et al (2012), adopsi teknologi pertanian dianggap identik dengan strategi adaptasi yang dilakukan petani dalam memerangi dampak buruk perubahan iklim. Sebagai hasilnya, literatur adopsi dapat diterapkan dalam studi mengenai adaptasi perubahan iklim. Literatur empiris juga luas pada karakteristik petani yang mempengaruhi adopsi teknologi pertanian. 


\section{Jurnal Agritexts Volume 42 Nomer 1 Mei 2018}

Persepsi Petani terhadap Produksi Padi

Berdasarkan Tabel 1 dapat diketahui bahwa persepsi petani terhadap produksi padi termasuk dalam kategori sedang sebanyak 30 orang atau $50 \%$. Hasil produksi padi dari varietas unggul baru Inpari 30 dan 33 yang telah diterapkan meningkat dari penggunaan varietas lainnya. Hal ini didukung pula dengan penerapan sistem tanam jajar legowo super di lahan usahatani responden. Hasil produksi padi sesuai dengan informasi saat sosialisasi gelar teknologi jarwo super menggunakan varietas unggul baru Inpari 30 dan 33 yaitu mencapai 10-11 ton/Ha GKP.

\section{Persepsi Petani terhadap Harga Beras}

Berdasarkan Tabel 1 dapat diketahui bahwa persepsi petani terhadap harga beras dalam kategori sedang yaitu sebanyak 41 orang atau $68,33 \%$. Hal ini karena harga beras dari varietas unggul baru Inpari 30 dan 33 saat panen semuanya dibeli oleh pemerintah dengan harga sesuai dengan kesepakatan awal pada MOU (Memorandum of Understanding) yaitu sebesar 4350/Kg. Persepsi petani terhadap harga beras dalam kategori sedang karena harga jual beras varietas unggul baru Inpari 30 dan 33 tidak jauh berbeda dengan harga jual beras varietas lokal dengan kisaran harga 4000/Kg nya.

\section{Persepsi Petani terhadap Rasa Nasi}

Berdasarkan Tabel 1 dapat diketahui bahwa persepsi petani terhadap rasa nasi termasuk dalam kategori buruk yaitu sebanyak 35 orang atau 58,33\%, kategori sedang sebanyak 19 orang atau 31,67\% dan sisanya kategori baik sebanyak 13 orang atau $21,67 \%$. Hal ini karena hasil panen dari varietas unggul baru Inpari 30 dan 33 tidak dikonsumsi sendiri oleh petani melainkan hasil panen langsung dibeli semua oleh pemerintah sesuai dengan perjanjian awal saat gelar teknologi ini dicanangkan, sehingga sebagaian besar responden belum merasakan rasa nasi dari varietas unggul baru Inpari 30 dan 33. Responden yang berpersepsi baik rata-rata mereka yang mengikuti uji rasa saat temu lapang jarwo super pada tanggal 5 Desember 2016, menurut responden rasa nasi dari Inpari 30 sama saja dengan rasa nasi varietas lainnya seperti IR64. Hasil persepsi petani terhadap rasa nasi dalam kategori buruk karena petani yang menggunakan VUB Inpari 30 dan 33 tidak secara langsung mengkonsumsi nasi dari hasil panen VUB Inpari 30 dan 33, sehingga untuk penilaian yang dilakukan responden bersifat negatif. Menurut Indraningsih (2011), faktorfaktor yang mempengaruhi keputu- 


\section{Ningtyas, Suwarto, Wijianto, Persepsi Petani, Rank,נ,}

san petani untuk mengadopsi teknologi adalah manfaat langsung dari teknologi yang berupa keuntunganrelatif (termasuk keuntungan ekonomi yang lebih tinggi), kesesuaian teknologiterhadap nilainilai sosial budaya, cara dan kebiasaan berusahatani, kerumitan penerapan teknologi, serta persepsi petani terhadap pengaruh media/ informasiinter personal sebagai penyampai teknologi yang komunikatif bagi petani.
Hubungan antara Faktor-faktor Pembentuk Persepsi dengan Persepsi Petani terhadap Varietas Unggul Baru Inpari $\mathbf{3 0}$ dan 33

Penelitian ini dilakukan untuk mengetahui hubungan antara faktorfaktor pembentuk persepsi dengan persepsi petani terhadap varietas unggul baru Inpari 30 dan 33 di Desa Tanjungsari, menggunakan analisis korelasi rank Spearman $\left(r_{s}\right)$ dengan program SPSS 17.0 for windows. Berikut disajikan pada Tabel 2.

Tabel 2. Hubungan Faktor-Faktor Pembentuk Persepsi dengan Persepsi Petani Terhadap Varietas Unggul Baru Inpari 30 dan 33

\begin{tabular}{llccl}
\hline \hline & \multirow{2}{*}{$\begin{array}{c}\text { No. } \\
\text { paktor-faktor pembentuk } \\
\text { persepsi }\end{array}$} & \multicolumn{2}{c}{$\begin{array}{c}\text { Persepsi petani terhadap Varietas } \\
\text { Unggul Baru Inpari } 30 \text { dan 33 }\end{array}$} & \multirow{2}{*}{ Keterangan } \\
\cline { 3 - 4 } & \multicolumn{2}{c}{$\begin{array}{c}\mathrm{r}_{\mathrm{s}} \\
\text { Unitung }\end{array}$} & \\
\hline 1. & Umur & 0,025 & 0,190 & Tidak Signifikan \\
2. & Tingkat pendidikan formal & 0,096 & 0,735 & Tidak Signifikan \\
3. & Pendidikan non formal & $0,650^{* *}$ & 6,514 & Signifikan \\
4. & Lama berusahatani & $-0,025$ & $-0,190$ & Tidak Signifikan \\
5. & Luas lahan & $-0,057$ & $-0,435$ & Tidak Signifikan \\
6. & Status kepemilikan lahan & 0,057 & 0,435 & Tidak Signifikan \\
\hline \hline
\end{tabular}

Sumber : Analisis Data Primer, 2017

Hubungan antara Umur dengan Persepsi Petani terhadap Varietas Unggul Baru Inpari $\mathbf{3 0}$ dan $\mathbf{3 3}$

Berdasarkan Tabel 2 dapat diketahui bahwa nilai koefisien korelasi $\left(r_{s}\right)$ sebesar 0,025 , dengan $t$ hitung sebesar $(0,190)$ dan $t$ tabel sebesar $(2,009)$, sehingga dapat diketahui bahwa $\mathrm{t}$ hitung $<\mathrm{t}$ tabel pada taraf signifikansi $95 \%$ maka $\mathrm{H}_{0}$ diterima dan $\mathrm{H}_{1}$ ditolak, yang artinya tidak ada hubungan yang signifikan antara umur dengan persepsi petani terhadap varietas unggul baru Inpari 30 dan 33 di Desa Tanjungsari. Hal ini menunjukkan bahwa persepsi petani terhadap varietas unggul baru Inpari 30 dan 33 tidak berhubungan dengan perbedaan tingkat umur responden.

Hasil analisis yang menunjukkan tidak adanya hubungan signifikan antara umur dengan 
persepsi petani terhadap varietas unggul baru Inpari 30 dan 33 karena umur tidak memberikan perubahan bagi responden dalam memberikan persepsi. Perbedaan usia atau bertambahnya umur responden tidak berhubungan dengan baik maupun buruk persepsi petani terhadap varietas unggul baru Inpari 30 dan 33. Hasil penelitian ini tidak sesuai dengan pernyataan Soekartawi (2005), rata-rata petani Indonesia yang cenderung tua sangat berpengaruh pada produktivitas sektor pertanian Indonesia. Petani berusia tua biasanya cenderung sangat konservatif dalam menyikapi perubahan atau inovasi teknologi. Berbeda halnya dengan petani yang berusia muda.

\section{Hubungan antara Tingkat Pendi-} dikan Formal dengan Persepsi Petani terhadap Varietas Unggul

\section{Baru Inpari $\mathbf{3 0}$ dan $\mathbf{3 3}$}

Berdasarkan Tabel 2 dapat diketahui bahwa nilai koefisien korelasi $\left(r_{s}\right)$ sebesar 0,096 , dengan $t$ hitung sebesar $(0,735)$ dan $t$ tabel sebesar (2,009), sehingga dapat diketahui bahwa $\mathrm{t}$ hitung < $\mathrm{t}$ tabel pada taraf signifikansi 95\% maka $\mathrm{H}_{0}$ diterima dan $\mathrm{H}_{1}$ ditolak, yang artinya tidak ada hubungan yang signifikan antara tingkat pendidikan formal dengan persepsi petani terhadap varietas unggul baru Inpari 30 dan 33 di Desa Tanjungsari. Hal ini menunjukkan bahwa persepsi petani terhadap varietas unggul baru Inpari 30 dan 33 tidak berhubungan dengan perbedaan tingkat pendidikan formal responden sehingga tidak memberikan perubahan persepsi responden.

Pendidikan yang semakin tinggi diharapkan dapat semakin mudah merubah sikap dan perilaku untuk bertindak lebih rasional (Soekartawi, 2005). Persepsi petani terhadap varietas unggul baru Inpari 30 dan 33 sedang. Tinggi rendahnya tingkat pendidikan formal petani tidak berhubungan dengan tingkat persepsi terhadap varietas unggul baru Inpari 30 dan 33. Hal ini karena pengetahuan tentang varietas unggul baru Inpari 30 dan 33 didapatkan melalui informasi yang diperoleh dari kegiatan yang bukan berasal dari hasil pendidikan formal. Melainkan responden mendapatkannya dari pendidikan non formal yaitu kegiatan penyuluhan dan pelatihan yang terkait dengan varietas unggul baru Inpari 30 dan 33.

\section{Hubungan antara Pendidikan Non Formal dengan Persepsi Petani terhadap Varietas Unggul Baru Inpari $\mathbf{3 0}$ dan $\mathbf{3 3}$ \\ Berdasarkan Tabel 2 dapat diketahui bahwa nilai koefisien korelasi $\left(r_{s}\right)$ sebesar $0,650 * *$, dengan $t$ hitung sebesar $(6,514)$ dan $t$ tabel sebesar (2,679), sehingga dapat}




\section{Ningtyas, Suwarto, Wijianto, Persepsi Petani, Rank,נ,}

diketahui bahwa $\mathrm{t}$ hitung $>\mathrm{t}$ tabel pada taraf signifikansi $99 \%$ maka $\mathrm{H}_{0}$ ditolak dan $\mathrm{H}_{1}$ diterima, yang artinya terdapat hubungan yang sangat signifikan antara pendidikan non formal dengan persepsi petani terhadap varietas unggul baru Inpari 30 dan 33 di Desa Tanjungsari. Hal ini menunjukkan bahwa persepsi petani terhadap varietas unggul baru Inpari 30 dan 33 sangat berhubungan dengan perbedaan tingkat pendidikan non formal responden.

Hubungan yang sangat signifikan serta koefisien korelasi positif antara pendidikan non formal dengan persepsi petani terhadap varietas unggul baru Inpari 30 dan 33 menunjukkan bahwa persepsi petani sangat berhubungan dengan tingkat pendidikan non formal petani, semakin banyak petani mengikuti kegiatan penyuluhan dan pelatihan yang berhubungan dengan inovasi varietas unggul baru Inpari 30 dan 33 maka akan semakin baik pula persepsi petani terhadap varietas unggul baru Inpari 30 dan 33. Hasil penelitian ini sesuai dengan pernyataan Effendy (1993) semakin sering seseorang melibatkan diri dalam komunikasi, akan semakin kuat daya persepsinya. Pendidikan non formal yang diikuti oleh responden merupakan salah satu bentuk komunikasi untuk mendapatkan tambahan ilmu dan informasi. Frekuensi responden dalam mengi- kuti kegiatan penyuluhan dan pelatihan sangat baik karena responden sering mengikutinya dalam satu tahun terdapat 7 kali penyuluhan dan 4 kali pelatihan, sesuai dengan data distribusi reponden pendidikan non formal dikategorikan baik dengan responden sebanyak 24 orang atau 40 persen mengikuti kegiatan penyuluhan lebih dari 6 kali dan pelatihan sebanyak 4 kali dalam kurun waktu satu tahun. Tambahan informasi yang didapatkan responden dari pendidikan non formal secara signifikan dapat memberikan persepsi positif terhadap varietas unggul baru Inpari 30 dan 33 .

Hubungan antara Lama Berusahatani dengan Persepsi Petani terhadap Varietas Unggul Baru Inpari $\mathbf{3 0}$ dan $\mathbf{3 3}$

Berdasarkan Tabel 2 dapat diketahui bahwa nilai koefisien korelasi $\left(r_{s}\right)$ sebesar $-0,025$, dengan $t$ hitung sebesar $(-0,190)$ dan $t$ tabel sebesar (2,009), sehingga dapat diketahui bahwa $\mathrm{t}$ hitung $<\mathrm{t}$ tabel pada taraf signifikansi $95 \%$ maka $\mathrm{H}_{0}$ diterima dan $\mathrm{H}_{1}$ ditolak, yang artinya tidak ada hubungan yang signifikan antara lama berusahatani dengan persepsi petani terhadap varietas unggul baru Inpari 30 dan 33 di Desa Tanjungsari. Hal ini menunjukkan bahwa persepsi petani terhadap varietas unggul baru Inpari 30 dan 33 tidak berhubungan dengan per- 


\section{Jurnal Agritexts Volume 42 Nomer 1 Mei 2018}

bedaan tingkat lama berusahatani responden.

\section{Menurut Kartasapoetra} (1994) petani yang sudah lebih lama berusahatani memiliki pengalaman yang lebih banyak daripada petani pemula, sehingga sudah dapat membuat perbandingan dalam mengambil keputusan terhadap anjuran penyuluh. Pernyataan tersebut tidak didukung oleh hasil penelitian ini, bahwa tidak ada hubungan yang signifikan antara lama berusahatani dengan persepsi petani terhadap varietas unggul baru Inpari 30 dan 33. Meskipun sebagian besar petani sudah lebih dari 20 tahun menjalankan usahataninya tetapi tidak memberikan perubahan persepsi responden. Hal ini karena sebagian besar responden masih menganggap varietas lokal lebih baik daripada varietas unggul baru Inpari 30 dan 33, sehingga semakin sering responden mencoba varietas baru bila tidak cocok dengan kondisi lingkungan dan mengakibatkan kerugian pada usahataninya responden akan berpersepsi buruk pada varietas tersebut.

Hubungan antara Luas Lahan dengan Persepsi Petani terhadap Varietas Unggul Baru Inpari 30 dan 33

Berdasarkan Tabel 2 dapat diketahui bahwa nilai koefisien korelasi $\left(r_{s}\right)$ sebesar $-0,057$, dengan $t$ hitung sebesar $(-0,435)$ dan $t$ tabel sebesar (2,009), sehingga dapat diketahui bahwa $\mathrm{t}$ hitung $<\mathrm{t}$ tabel pada taraf signifikansi 95\% maka $\mathrm{H}_{0}$ diterima dan $\mathrm{H}_{1}$ ditolak, yang artinya tidak ada hubungan yang signifikan antara luas lahan dengan persepsi petani terhadap varietas unggul baru Inpari 30 dan 33 di Desa Tanjungsari. Hal ini menunjukkan bahwa persepsi petani terhadap varietas unggul baru Inpari 30 dan 33 tidak berhubungan dengan perbedaan tingkat luas lahan responden.

Petani yang mengusahakan luas lahan yang lebih tinggi akan lebih mudah merespon metodemetode penyuluhan pertanian karena mereka ingin memperoleh hasil-hasil pertanian yang lebih meningkat dari sebelumnya (Kartasapoetra, 1994). Keadaan di lapang menunjukkan luas lahan mayoritas responden yaitu 0,3 $\mathrm{Ha}$, termasuk dalam kategori lahan sempit. Sehingga responden tidak mau ambil resiko terlalu banyak untuk mencoba-coba hal yang baru atau tidak seperti kebiasaannya. Karena penggunaan varietas unggul baru Inpari 30 dan 33 ini termasuk dalam program jadi mau tidak mau petani harus menerapkan inovasi varietas unggul baru Inpari 30 dan 33 di lahan usahataninya. 


\section{Ningtyas, Suwarto, Wijianto, Persepsi Petani, Rank,נ,}

Hubungan antara Status Kepemilikan Lahan dengan Persepsi Petani terhadap Varietas Unggul Baru Inpari $\mathbf{3 0}$ dan $\mathbf{3 3}$

Berdasarkan Tabel 2 dapat diketahui bahwa nilai koefisien korelasi $\left(r_{s}\right)$ sebesar 0,057 , dengan $\mathrm{t}$ hitung sebesar $(0,435)$ dan $\mathrm{t}$ tabel sebesar $(2,009)$, sehingga dapat diketahui bahwa $\mathrm{t}$ hitung $<\mathrm{t}$ tabel pada taraf signifikansi $95 \%$ maka $\mathrm{H}_{0}$ diterima dan $\mathrm{H}_{1}$ ditolak, yang artinya tidak ada hubungan yang signifikan antara status kepemilikan lahan dengan persepsi petani terhadap varietas unggul baru Inpari 30 dan 33 di Desa Tanjungsari. Hal ini menunjukkan bahwa persepsi petani terhadap varietas unggul baru Inpari 30 dan 33 tidak berhubungan dengan perbedaan tingkat status kepe- milikan lahan responden. Petani sebagai pengelola usahatani berarti ia harus mengambil berbagai keputusan didalam memanfaatkan lahan yang dimilikinya atau disewa dari petani lainnya untuk kesejahteraan hidup keluarganya (Rodjak, 2006). Keadaan di lapang, menunjukkan bahwa responden dengan berbagai ragam kepemilikan lahan seperti pemilik penggarap, sewa maupun gadai tidak memberikan perubahan bagi responden dalam memberikan persepsi. Karena inovasi varietas unggul baru Inpari 30 dan 33 ini termasuk program gelar teknologi dari pemerintah, sehingga petani yang menerima program mau tidak mau harus menggunakan varietas unggul baru Inpari 30 dan 33 di lahan usahatani miliknya.

\section{Perbedaan Persepsi Petani terhadap Varietas Unggul Baru Inpari 30 dan $\mathbf{3 3}$}

Tabel 3. Hasil Analisis Uji Beda

\begin{tabular}{|c|c|c|c|c|c|}
\hline No. & $\begin{array}{l}\text { Perbedaan Persepsi Petani terhadap } \\
\text { Varietas Unggul Baru Inpari } 30 \text { dan } 33\end{array}$ & $\mathrm{~N}$ & Mann-Whitney & $\begin{array}{l}\text { Asymp. Sig (2- } \\
\text { tailed) }\end{array}$ & $Z_{\text {hit }}$ \\
\hline 1. & $\begin{array}{l}\text { Petani Pengguna VUB Inpari } 30 \text { dan } \\
33\end{array}$ & 30 & & & \\
\hline 2. & $\begin{array}{l}\text { Petani Tidak Menggunakan VUB } \\
\text { Inpari } 30 \text { dan } 33\end{array}$ & 30 & 216.000 & 0.000 & $-3,693$ \\
\hline
\end{tabular}

Sumber : Analisis Data Primer 2017

Tabel 3 menunjukkan bahwa terdapat perbedaan yang signifikan antara persepsi petani pengguna VUB Inpari 30 dan 33 dengan persepsi petani yang tidak menggunakan VUB Inpari 30 dan 33. Nilai Mann-Whitney sebesar 216.000,
Asymp.Sig sebesar 0,000 serta Zhit sebesar -3,693. Maka Zhit> Ztabel yaitu $3,693>1,96$, sehingga $\mathrm{HO}$ ditolak dan $\mathrm{H} 1$ diterima, yang berarti bahwa terdapat perbedaan yang sangat signifikan antara persepsi petani pengguna VUB Inpari 30 dan 


\section{Jurnal Agritexts Volume 42 Nomer 1 Mei 2018}

33 dengan persepsi petani tidak menggunakan VUB Inpari 30 dan 33. Hal ini menunjukkan bahwa persepsi petani pengguna VUB Inpari 30 dan 33 lebih baik dari perspesi petani tidak menggunakan VUB Inpari 30 dan 33.

Perbedaan persepsi antara petani pengguna VUB Inpari 30 dan 33 dengan petani tidak menggunakan VUB Inpari 30 dan 33 merupakan suatu keberhasilan dari inovasi yang telah dilaksanakan. Karena petani pengguna VUB Inpari 30 dan 33 yang telah menerapkan inovasi ini dapat meningkatkan hasil produksi dari yang biasanya menggunakan varietas lokal mendapat $6-7$ ton/Ha GKP tetapi dengan menggunakan varietas unggul baru Inpari 30 dan 33 mendapatkan hasil mencapai 10-11 ton/Ha GKP. Pengalaman dari petani pengguna VUB Inpari 30 dan 33 dapat menjadi perbedaan pula dengan petani tidak menggunakan VUB Inpari 30 dan 33. Sehingga diharapkan dengan keberhasilan petani yang telah menerapkan VUB Inpari 30 dan 33 dapat menjadi contoh bagi petani yang belum menerapkan VUB Inpari 30 dan 33 ini.

\section{KESIMPULAN DAN SARAN \\ Kesimpulan}

Hasil penelitian menunjukkan bahwa faktor-faktor pembentuk persepsi petani yaitu umur responden dalam penelitian ini sebagian besar berada pada usia antara 45 64 tahun dengan prosentase sebesar $60,00 \%$, tingkat pendidikan formal yang telah ditamatkan oleh responden dalam penelitian ini sebagian besar adalah tamat SMA dengan prosentase sebesar 43,3\%, pendidikan non formal yang diikuti oleh responden termasuk dalam kategori baik, yaitu sebagian besar responden mengikuti penyuluhan sebanyak 3-4 kali dalam satu tahun dan pelatihan sebanyak 4 kali dalam satu tahun, dengan prosentase sebesar 40\%, lama berusahatani mayoritas responden masuk dalam kategori 25 - 29 tahun dengan prosentase sebesar 38,33\%, luas lahan petani dalam kategori sempit yaitu sebagian besar responden mempunyai luas lahan antara 0,25 $0,3 \mathrm{Ha}$ dengan prosentase sebesar $68,3 \%$ dan status kepemilikan lahan sebagian besar responden sebagai penyewa dengan prosentase sebesar $78,3 \%$.

Persepsi petani terhadap varietas unggul baru Inpari 30 dan 33 di Desa Tanjungsari Kecamatan Banyudono Kabupaten Boyolali dikategorikan sedang dengan prosentase sebesar $80 \%$ Perepsi petani terhadap sistem pemeliharaan termasuk ketagori baik dengan prosentase sebesar 53,33\%, persepsi petani terhadap ketahanan HPT 


\section{Ningtyas, Suwarto, Wijianto, Persepsi Petani, Rank,נ,}

termasuk dalam kategori buruk dengan prosentase sebesar $50 \%$, persepsi petani terhadap produksi padi termasuk dalam kategori sedang dengan prosentase sebesar $50 \%$, persepsi petani terhadap harga beras termasuk dalam kategori sedang dengan prosentase sebesar $68,33 \%$ dan persepsi petani terhadap rasa nasi termasuk dalam kategori buruk dengan prosentase sebesar $58,33 \%$.

Hubungan antara faktor-faktor pembentuk persepsi dengan persepsi petani terhadap varietas unggul baru Inpari 30 dan 33 di Desa Tanjungsari Kecamatan Banyudono Kabupaten Boyolali.Terdapat hubungan yang signifikan antara pendidikan non formal dengan persepsi petani terhadap varietas unggul baru Inpari 30 dan 33, pada taraf kepercayaan sebesar $99 \%$. Sedangkan untuk faktor umur, pendidikan formal, lama berusahatani, luas lahan dan status kepemilikan lahan tidak terdapat hubungan yang signifikan dengan persepsi petani terhadap varietas unggul baru Inpari 30 dan 33. Dan terdapat perbedaan yang signifikan antara persepsi petani pengguna VUBInpari 30 dan 33 dengan petani tidak menggunakan VUB Inpari 30 dan 33.

\section{Saran}

Berdasarkan hasil penelitian dan pembahasan, maka saran yang dapat diberikan adalah: Sebaiknya frekuensi kegiatan penyuluhan dan pelatihan di Desa Tanjungsari lebih ditingkatkan dan kegiatannya divariasikan seperti melakukan kunjungan, studi banding, sekolah lapang dan demplot. Agar petani memperoleh pengalaman yang lebih.

\section{DAFTAR PUSTAKA}

Effendy, Onong Uchjana. 1993. IImu, Teori \& Filsafat Komunikasi. Bandung : PT. Citra Aditya Bakti.

Humaida, U. 2009. Varietas Unggul Baru. Seputar Pembangunan Pembangunan Indonesia. (http: www.sukatani-banguntani.blog spot.com, diakses 5 Januari 2017).

Indraningsih, K S. 2011. Pengaruh Penyuluhan terhadap Keputusan Petani dalam Adopsi Inovasi Teknologi Usahatani Terpadu. J. Agro Ekonomi 29(1): 1-24.

Kartasapoetra, A.G. 1994. Teknologi Penyuluhan Pertanian. Jakarta: Bumi Aksara.

Liliweri, A. 1994. Komunikasi Verbal dan Non Verbal. Bandung: PT. Citra Aditya Bakti.

Londra I M dan Aribawa I B. 2014. Tampilan Varietas Unggul Baru Inpari 7 di Lahan Sawah Dataran Medium Beriklim Basah di Bali. Hal 101 - 109. Dalam Prosiding Seminar Nasional "Inovasi Teknologi Pertanian Spesifikasi Lokasi". 
Balai Pengkajian Teknologi Pertanian Bali.

Monografi Desa Tanjungsari 2017.

Mulyana, D. 2001. IImu Komunikasi, Suatu Pengantar. Bandung: Remaja Rosdakarya.

Ndambiri $\mathrm{H}$ K, Ritho $\mathrm{C} \mathrm{N}$, and Mbogoh S G. 2012. An Evaluation of Farmers' Perception of and Adaptation to the Effects of Climate Change in Kenya. J. International of Food and Agricultural Economics 1(1): 75 $-96$.

Priyanto G, Soegiyono dan Pratama F. 2005. Model Penggunaan Benih Bermutu dalam Hubungannya dengan Faktor Persepsi dan Pengambilan Keputusan Petani terhadap Benih Padi. J. KPM 2(1): 45 52.

Rakhmat, J. 2007. Psikologi Komunikasi Edisi Revisi. Bandung: Remaja Rosdakarya.

Rodjak, A. 2006. Manajemen Usahatani Jilid II. Bandung : Pustaka Gratuna.
Saenong, S., M. Azrai, dan Rahmawati. 2007. Pengelolaan Benih Jagung. Dalam Buku jagung. Pusat Penelitian dan Pengembangan Tanaman Pangan. Departemen Pertanian. Diakses. (http://balitsereal.litbang.dept an.go.id). 5 Januari 2017.

Siegel, S. 1997. Statistik Non Parametrik untuk IImu-ilmu Sosial. Jakarta: PT Gramedia Pustaka.

Singarimbun, $M$. dan Effendi, $S$. 2006. Metode Penelitian Survai. Yogyakarta: LP3ES.

Soekartawi. 2005. Agribisnis Teori dan Aplikasinya. Jakarta :Raja Grafindo Persada.

Sugandi, D dan Pudji, U.A. 2011. Persepsi dan Minat Adopsi Petani terhadap VUB Padi Sawah Irigasi di Provinsi Bengkulu. BPTP Bengkulu.

Suwarto dan N. Prihatiningsih. 2007. Perakitan Varietas Unggul Padi Tipe Baru (PTB) untuk Mengatasi Pelandaian Produksi Padi Sawah. Laporan Penelitian. Purwokerto: Fakultas Pertanian Universitas Jendral Soedirman. 